University of Nebraska - Lincoln

DigitalCommons@University of Nebraska - Lincoln

Publications from USDA-ARS / UNL Faculty

U.S. Department of Agriculture: Agricultural

Research Service, Lincoln, Nebraska

2011

Indices for Soil Management Decisions

Douglas L. Karlen

USDA-ARS-NLAE, doug.karlen@ars.usda.gov

Brian J. Wienhold

USDA-ARS, Brian.Wienhold@ars.usda.gov

Shujiang Kang

USDA-NRCS

Ted M. Zobeck

USDA-ARS, ted.zobeck@ars.usda.gov

Susan S. Andrews

USDA-NRCS

Follow this and additional works at: https://digitalcommons.unl.edu/usdaarsfacpub

Karlen, Douglas L.; Wienhold, Brian J.; Kang, Shujiang; Zobeck, Ted M.; and Andrews, Susan S., "Indices for Soil Management Decisions" (2011). Publications from USDA-ARS / UNL Faculty. 1381.

https://digitalcommons.unl.edu/usdaarsfacpub/1381

This Article is brought to you for free and open access by the U.S. Department of Agriculture: Agricultural Research Service, Lincoln, Nebraska at DigitalCommons@University of Nebraska - Lincoln. It has been accepted for inclusion in Publications from USDA-ARS / UNL Faculty by an authorized administrator of DigitalCommons@University of Nebraska - Lincoln. 


\title{
Indices for Soil Management Decisions
}

\author{
Douglas L. Karlen, Brian J. Wienhold, Shujiang Kang, \\ Ted M. Zobeck, and Susan S. Andrews
}

\begin{abstract}
lobal efforts to identify and develop soil quality indices that can accurately and efficiently $\checkmark$ quantify effects of soil and crop management began to emerge around the world during the latter portion of the 20th century. This occurred as people became more aware that soil is a unique, nonrenewable resource that nurtures and sustains human civilizations (McNeill and Winiwater, 2004). These efforts have been further encouraged by a growing awareness of the multiple ecosystem services that soil resources provide to sustain food security, environmental quality, ecological functions, and most recently feedstock production for biofuels (Doran et al., 1996; Bouma, 2005; Lal, 2007). In addition to serving as assessment tools, soil quality indices also provide land managers with a better understanding of how their short-term, economically driven management decisions are affecting soil properties and processes over time.
\end{abstract}

\section{Why Are Indices Needed?}

Historically, human neglect of soil resources resulted in the demise of dominant societies and entire cultures (Lowdermilk, 1953; Hillel, 1991; Diamond, 2005). For example, soils of the Tikal rainforest never fully recovered from the Mayan occupation and abandonment that occurred more than 1000 years ago. In southern Mesopotamia, a once thriving land of lush fields is now largely desolate. What were once great cities are now barren mounds of clay rising out of the desert in mute testimony to the glory of a spent civilization.

In the United States, one of the most severe natural resource disasters occurred during the 1930s as a result of ignorance regarding the fragility of the Great Plains' soil resources, which just three decades earlier were described as "indestructible and immutable" in the 1909 Bureau of Soils Bulletin 55 (Whitney, 1909). Implementation of a wheat (Triticum aestivum L.)-fallow cropping system and use of intensive tillage throughout the Great Plains contributed to the Dust Bowl that fostered Hugh Hammond Bennett's 1933 indictment of Americans as "the great destroyers of land" (Baumhardt, 2003). Water erosion associated with cotton (Gossypium hirsutum L.) production in the southern United States and continuous oat (Avena sativa L.) and wheat in

D.L. Karlen, USDA-ARS, National Laboratory for Agriculture and the Environment (NLAE), 2110 University Blvd. Ames, IA 50011 (Doug.Karlen@ars.usda.gov); B.J. Wienhold, USDA-ARS, 305 Entomology Hall, University of Nebraska, East Campus, Lincoln, NE 68583; S. Kang and S.S. Andrews, USDA-NRCS, ENTSC, 200 E. Northwood, Ste. 410, Greensboro, NC 27401; T.M. Zobeck, USDA-ARS, Wind Erosion and Water Conservation Research Unit, 3810 4th St., Lubbock, TX 79415. The U.S. Department of Agriculture offers its programs to all eligible persons regardless of race, color, age, sex, or national origin, and is an equal opportunity employer.

doi:10.2136/2011.soilmanagement.c3

Copyright () 2011. American Society of Agronomy and Soil Science Society of America, 5585 Guilford Road, Madison, WI 53711, USA. Soil Management: Building a Stable Base for Agriculture. Jerry L. Hatfield and Thomas J. Sauer (ed.) 
the Driftless Region (Major Land Resource Area [MLRA] 105) of the upper Midwest were also responsible for the destruction of fragile soil resources. By 1934, the U.S. government estimated that $1.4 \times 10^{7}$ ha $\left(3.5 \times 10^{7}\right.$ ac) of cultivated croplands had been "essentially destroyed" by soil erosion, while 4.0 $\times 10^{7}$ ha $\left(1 \times 10^{8} \mathrm{ac}\right)$ had lost "all or most of the topsoil (USDA, 1934). Rapid and devastating loss of topsoil, and with it the homes and livelihoods of many Americans, led to the establishment of the Soil Erosion Service (now the Natural Resources Conservation Service [NRCS]) and the Coon Creek Watershed project to demonstrate how to best address erosion problems (Hart, 2009). With regard to indices, addressing soil erosion also led to the early development of tools, including the Universal Soil Loss Equation (USLE), Soil Loss Tolerance Standard (T), Revised Universal Soil Loss Equation (RUSLE), Water Erosion Prediction Project (WEPP), and Wind Erosion Equation (WEQ), in this region. During the past 75 years, these tools have helped land managers make much better management decisions and have significantly reduced erosion, but they do not address the full range of ecosystem services provided by soils (Soil and Water Conservation Society, 2008).

\section{The Soil Quality Concept}

The "soil quality" concept was introduced by Warkentin and Fletcher (1977) to guide the use and allocation of labor, fiscal resources, and other inputs to meet increasing demands being placed on agriculture. In subsequent decades, the soil quality concept has educated professionals, producers, and the general public about the critical functions soils perform. It has led to the development of assessment tools for comparing management practices and quantifying changes in dynamic soil properties through time. Among the factors that originally slowed acceptance of the concept were perceptions that soil quality assessment was simply an extension of productivity assessments or new soil suitability (interpretations of production capability) ratings as presented in soil surveys and not inclusive of other ecosystem functions or services. Several also argued that soil quality considerations can be traced back to ancient agricultural times when they were used for soil fertility or productivity assessments (Krupenikov, 1981; Yaalon, 1997; Patzel et al., 2000).

Borggaard (2006) stated that although launching the soil quality concept definitely increased the focus on soils, the multifunctionality of the concept has been difficult to handle. For example, a highly fertilized soil may have high quality as a medium for agricultural crop production, but low quality with regard to protection of groundwater and surface water from nitrate pollution. The challenge is to develop the concept so it can integrate and operationally recognize the simultaneity of diverse and often conflicting soil functions. Others argue that the focus should simply be on "quality soil management" rather than on "soil quality" because of the impact that human decision-making and the management practices that are chosen have on highly variable and unique resources (Sojka and Upchurch, 1999; Sojka et al., 2003; Letey et al., 2003). In reality there is little difference between the two concepts - both focus on improved soil function, the latter attempting to offer assessment techniques to ensure quality soil management is working as intended. Nevertheless, this debate is consistent with that facing the entire soil science discipline. As soil science becomes more integrated with geosciences, environmental sciences, and engineering (Baveye, 2006; Lal, 2007), all are facing new demands that require many traditional disciplinary concepts and theories to be reexamined and perhaps even redefined in an interdisciplinary light.

The concepts of soil quality and land quality share many similar components, especially with regard to indexing land management and environmental issues (Carter, 2002; Bouma, 2002). Anderson and Magleby (1997) suggested that using soil quality to focus on soil functions would better meet the needs of environmentally sound land management. Herrick (2000) suggested that indexing soil quality under various landscapes would be an effective tool for land management. Such efforts could easily complement the land capability and suitability indices developed by the NRCS and thus provide a consistent approach for soil quality assessment (Lal, 1999; Bouma, 2004). Integrating land and soil quality indices could help solve environmental problems 
across spatial scales. Combining soil quality indexing with information regarding the specific capacity of soils to provide critical functions under different landscape features could help guide and improve land management, especially with regard to assessing impacts of various land use decisions. For example, in New Zealand, the national soil quality monitoring framework provided a major legislative basis for the Resource Management Act (Sparling and Schipper, 2002; Sparling et al., 2004). The European Union identified soil quality as a major focus for environmental assessment by adopting a Thematic Strategy on Soil Protection (Commission of the European Communities, 2006). Research and applications for soil quality assessment and indexing were also important topics at the 18th World Congress of Soil Sciences held in Philadelphia, PA in 2006.

Overall, we contend that both proponents and opponents of the soil quality concept want the same outcome-an improved public awareness of the importance of soil resources and a better understanding of how short-term economic decisions can affect long-term soil properties and processes. This is reflected in the USDA-NRCS strategic plan for 2005-2010 (USDA-NRCS, 2006) where understanding and promoting soil quality was identified as a foundation mission goal for ensuring that the United States continues to have productive lands and a healthy environment. Finally, the importance of focusing on soil quality and its assessment protocols was confirmed by the 2004 special section in Science (11 June 2004) that recognized soil as "The Final Frontier" to highlight the importance of this resource and to draw attention to our incomplete knowledge of soil properties, processes, and functions. The articles illustrated how processes occurring in the top few centimeters of Earth's surface are the basis of all life on dry land, but concluded that the opacity of soil has severely limited our understanding of how it functions (Sugden et al., 2004). Based on the evolution of the concept during the past two decades, it seems likely that the soil quality concept, along with the theories, techniques, and logistics to support its assessment will continue to evolve with an ever-increasing understanding of soil resources and the changing needs associated with managing them for the benefit of humanity.

\section{Soil Quality Assessment Methods}

Soil quality scorecards were introduced during the 1990s as one of the first methods to assess soil quality (Harris et al., 1996; Romig et al., 1996; Shepherd, 2000; Shepherd et al., 2000). A scorecard and guidelines for tailoring them to local areas were among the first products developed by the NRCS-Soil Quality Institute (USDA-NRCS, 1999). The cards were developed and promoted primarily to build a basic awareness of soils and to help land managers document their efforts to improve them. Other assessment approaches include use of soil pits and the soil quality test kit (Fig. 3/1) developed by J.W. Doran, M. Sarrantonio, and others (Sarrantonio et al., 1996) to provide a hands-on understanding of how soil physical, chemical, and biological properties and processes change with time and from location to location. The kits, which emulate the "doctor's black bag," can be used to measure water

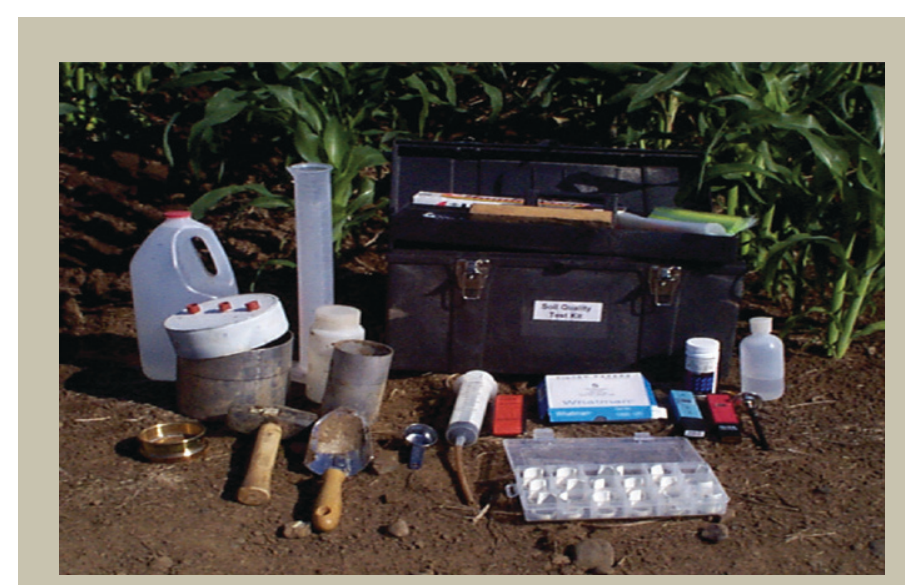

Fig. 3|1. A soil quality test kit, emulating the "doctor's black bag" was developed to demonstrate the importance of soil physical, chemical, and biological properties to the general practitioner and conservationist. 
infiltration, bulk density, soil respiration at field capacity, soil stability, soil water content, water holding capacity, water-filled pore space, soil temperature, soil $\mathrm{pH}$, electrical conductivity, and soil nitrate. When used with visual examination of soil profiles, the kit provides information that many conservationists, soil and crop consultants, and others have found useful for understanding spatial and temporal variability among soil resources (Doran et al., 1996; Liebig et al., 1996; USDA-NRCS, 1999).

More recently, the USDA-NRCS has recognized the importance of soil quality by incorporating the Soil Conditioning Index (SCI), a simple, linear predictive model to assess trends in soil organic carbon in crop management systems, into several policies and programs. The SCI was developed from data associated with a 12-yr field study (19481959) conducted near Renner, TX (Laws, 1961). The model was released initially for regional planning, and the NRCS Soil Quality Institute further calibrated the model before its national release and added a correction factor for soil texture to the original SCI. This improved the model's accuracy by requiring more biomass production to maintain the level of soil organic matter for coarse-textured soils (USDA-NRCS, 2003). The Institute then validated the SCI using data from longterm carbon studies around the United States. One evaluation, using nine long-term $C$ studies, showed positive trends in soil $\mathrm{C}$ were reflected by positive trends in the $\mathrm{SCI}$, while negative SCI trends were associated with negative soil $\mathrm{C}$ trends (Hubbs et al., 2002). Another study, using data from 52 western Texas sites, (Zobeck et al., 2007) showed that SCI values were not strongly correlated with total soil organic carbon. However, they were more strongly correlated with a specific soil $\mathrm{C}$ fraction known as particulate organic matter carbon, a more labile (changeable) form of $C$ related to recent organic inputs such as animal or green manure, crop residues, or plant roots. A more recent study of different cropping systems on the same soil in Colorado (Zobeck et al., 2008) showed the SCI to be more highly correlated with total soil organic C. Obviously, this is an area of research that needs additional efforts for many different regions and cropping systems.

Following passage of the 2002 U.S. Farm Bill, the SCI was adopted nationally as one factor for determining eligibility for the USDA Conservation Security Program (CSP) and the Environmental Quality Incentives Program (EQIP). However, one limitation of the SCI is that it focuses only on potential changes in soil organic matter. This is justified because if only one indicator is to be used, soil organic matter is often agreed on to be the best choice because of the multitude of soil physical, chemical, and biological properties and processes it influences (USDA-NRCS, 2003). Another limitation is that, while it is well known that soil carbon change is asymptotic, the model does not predict where on the curve a particular system may be. It only provides positive or negative trend information, even when a system has reached a steady state for carbon.

The Soil Management Assessment Framework (SMAF), as described by Andrews et al. (2004), is a measurement-based approach for assessing soil quality. This tool evolved from studies applying principles of systems engineering (Karlen et al., 1994a,b), economics, and ecology (Andrews and Carroll, 2001) to interpret soil physical, chemical, and biological data collected from various soil management studies. The SMAF provides a consistent three-step approach or framework for evaluating all types of cropping systems and management goals by: (i) suggesting goal appropriate indicators, (ii) providing indicator interpretation within inherent soil and climatic context, and (iii) if desired, combining the ratings into an overall assessment of dynamic soil function (Andrews et al., 2002a,b, 2004). The SMAF has successfully distinguished between "dynamic soil properties" (or quality), which are responsive to current or recent management decisions on the human time scale, and "inherent soil properties," which are determined by basic soil forming factors and relatively unresponsive to recent management (Tugel et al., 2005).

A similar indexing approach has also been incorporated into the Agroecosystem Performance Assessment Tool (AEPAT). The AEPAT is a computer program designed to assess agronomic socioeconomic and environmental performance of soil and crop management practices (Liebig et al., 2004). Measured indicators are assigned by the user to various soil functions (e.g., food/ feed production, nutrient cycling), as well as social and economic indicators such as 
net profit or quality of life indicators. The functions are weighted by the user, and individual function scores are combined into an index. The AEPAT was used to compare cropping system effects on soil quality using information from several long-term studies throughout the Great Plains (Wienhold et al., 2006), but it is designed primarily for soil scientists (most likely researchers) because indicators, their relationships to soil function, and weighting factors must all be defined by the user.

A simplified two-step version of SMAF with slightly different indicators is used in the Cornell Soil Health Assessment program (http://soilhealth.cals.cornell.edu/ index.htm, verified 30 Aug. 2010), which was the first commercially available program to offer balanced assessments of soil physical, chemical, and biological quality (Gugino et al., 2007). This program was developed to facilitate education about soil health, guide farmers and land managers in their selection of soil management practices, provide monitoring for the NRCS, and indirectly increase land values by providing information regarding the soil's overall condition. Measured biological, chemical, and physical indicator values are interpreted using various nonlinear response curves, modified by soil texture. The tool has been found to be sensitive to soil and crop management practices (e.g., tillage, crop rotation, and animal manure) on hundreds of farms across New York and vicinity. Results are relevant to what has been defined as critical soil functions (Doran and Parkin, 1994), consistent and reproducible, easy to sample for, and economical for soil-testing laboratories to implement.

All three of these assessment tools (SMAF, AEPAT, and the Cornell Soil Health Test) focus on "dynamic soil quality," which describes the current soil condition created by recent soil management decisions, rather than "inherent soil quality," which reflects the basic soil forming factors of climate, parent material, time, topography, and vegetation (Seybold et al., 1998).

\section{Development of Soil Quality Indices}

Figures 312 and $3 \mid 3$ illustrate two important points with regard to developing indices for soil quality assessment. Figure $3 / 2$ illustrates inherent differences between soils and why meaningful comparisons can be made only by soil map unit component or phase (with similar surface texture and slope) for defined locations. The fluctuation about either soil (Fig. 3|2) shows there will be steady-state differences over time. The important interpretation that assessments must help identify is the trend in that fluctuation (Fig. 3|3). Are soil resources being improved, degraded, or at least maintained? With regard to the sometimes controversial issue of what baseline condition (e.g., native prairie, fencerow, cemetery, pasture, cultivated field) to use for indexing soil quality, we conclude that it does not matter. Since it is not possible to go back in time and many of the suggested reference conditions would not require the same soil functions as current land use, the most meaningful approach for examining long-term effects is to measure soil management effects every 3 to 5 yr using the same sampling and

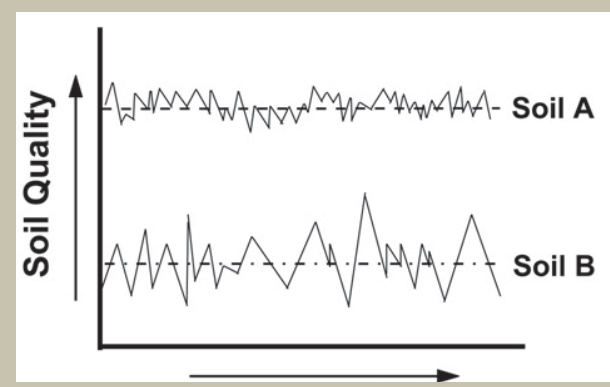

Fig. 3|2. Conceptualization of inherent soil quality differences between two soils. Adapted from Karlen et al. (2001).

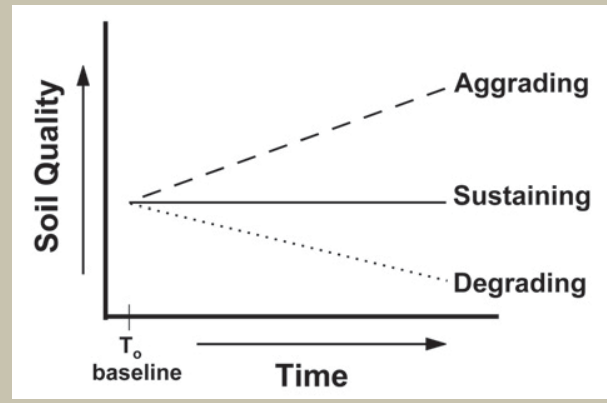

Fig. 3|3. Conceptualization of dynamic soil quality trends from time zero (T0). Adapted from Seybold et al. (1998). 
indicator interpretations to quantify important trends. This approach provides the information needed to know if the practices being used are causing critical soil functions to improve, decline, or at least remain stable (Fig. 3|3). When monitoring over time is not possible, sampling similar soils under different steady-state management conditions allows an inventory of soil function related to management (Tugel et al., 2009).

\section{Recent Soil Quality Assessment Studies}

Examples of ongoing research to improve soil quality indices include a national effort to use the SMAF to quantify environmental benefits of public investment in conservation practices. Soil samples are being collected at 14 benchmark watershed sites associated with the ARS Conservation Effects Assessment Project (CEAP). The overall goal of CEAP is to quantify how agricultural management practices are influencing soil and water quality (NRC,
1993), thus providing an excellent dataset for validating the SMAF. Recognizing that high rates of soil erosion, loss of soil organic matter, imbalanced soil fertility, and chemical or heavy metal contamination continue to be critical soil quality issues (Larson and Pierce, 1991: Doran and Parkin, 1994; Karlen et al., 2001, 2003, 2006), the SMAF (Andrews et al., 2004) was chosen for this assessment because of its design to use biological, chemical, and physical indicators in an organized and consistent manner

A survey approach was chosen to identify the most limiting soil properties or processes within each benchmark watershed (Fig. 3|4). An initial assessment within the South Fork Watershed of the Iowa River (Karlen et al., 2008) provided the foundation for the overall CEAP soil quality program. Samples were collected from five to ten locations (as replicates) under three to five conservation practices within three to five soil map units in each watershed. At each sampling site, 20 soil cores were collected from the 0 - to 5 -cm depth using a soil probe with an inner diameter of 3.2

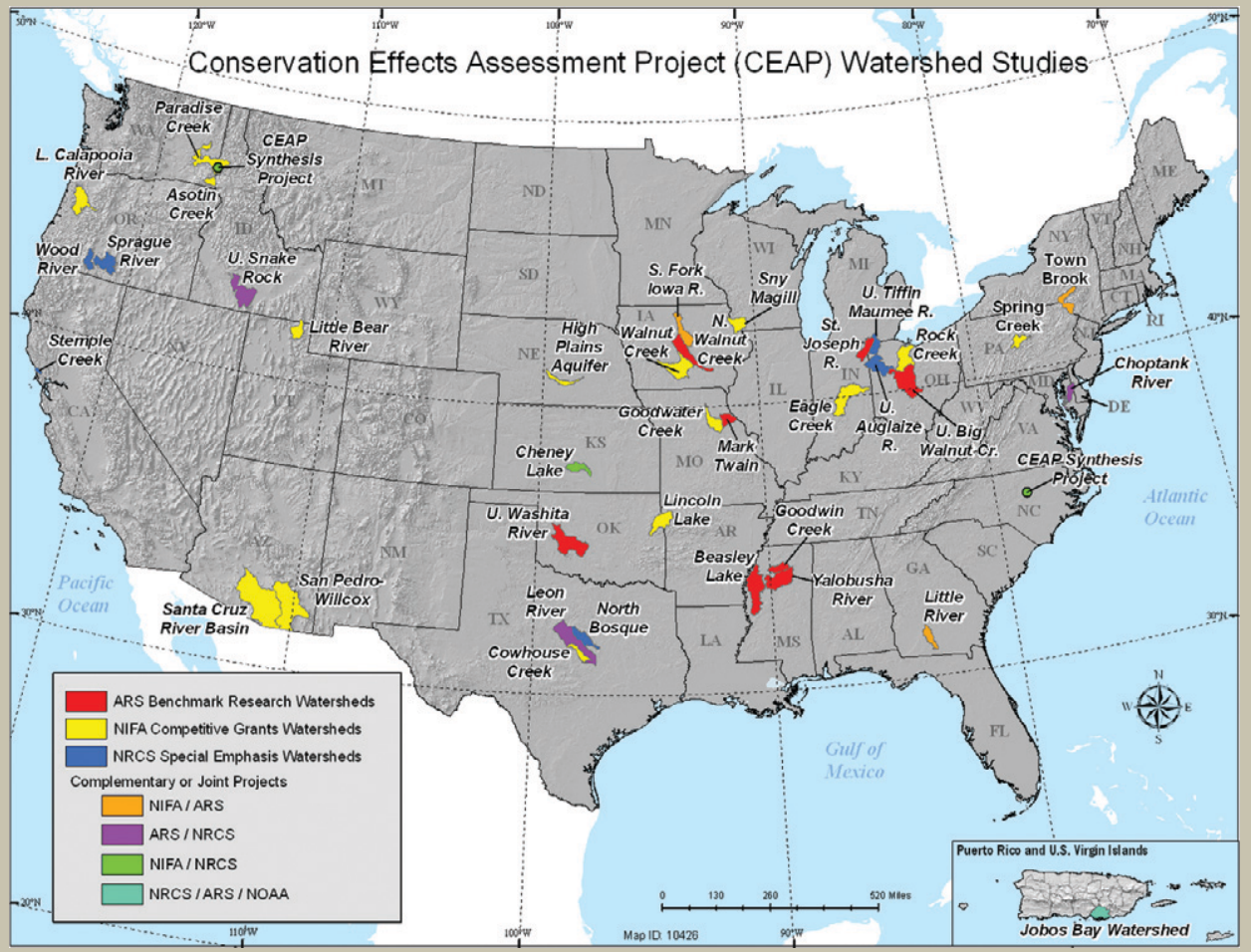

Fig. 3|4. Location of USDA-ARS Conservation Effects Assessment Project (CEAP) Benchmark Watersheds. 
$\mathrm{cm}$. Then, depending on the local research questions, either additional samples from lower depths were collected or more sites were sampled. All sampling sites were georeferenced, and soil map unit, landscape position, slope, and any evidence of wind, water, or tillage-induced soil erosion and periodic ponding or flooding was documented. Current and past management information from the land owner or operator was collected when possible. This included conservation practices, fertilizer and/or manure management histories, crop rotations, tillage practices, yields, and other pertinent information that is known to affect soil resources.

To date, 13 of 14 CEAP benchmark watersheds have been sampled, and soil analyses are nearly complete for five of them. A preliminary examination of the data shows that low SOM, especially on hilltops where water, wind, and tillage erosion (Schumacher et al., 2005) have decreased topsoil depth over time, is one of the most consistent findings. Areas receiving excess $\mathrm{P}$ through frequent animal manure applications often show increasing levels of soil-test $\mathrm{P}$ and an increased potential for surface water contamination through runoff that contains excessive levels of soluble P. This appears consistent with results from the initial South Fork watershed study (Karlen et al., 2008) that showed soil-test P ratings for upland soils were generally very high $\left(>31 \mu^{g^{-1}}\right.$ ) (Mallarino et al., 2002) but not to the levels (e.g., $>100 \mu \mathrm{g} \mathrm{g}^{-1}$ ) at which severe environmental impact would be expected. Lower soil-test $\mathrm{P}$ ratings in the depression areas were consistent with the higher $\mathrm{pH}$ in those soils. Soil-test $\mathrm{K}$ in the initial South Fork study was generally in an optimum range (131-170 $\mathrm{g} \mathrm{g} \mathrm{g}^{-1}$ ) for corn (Zea mays L.) and soybean [Glycine max (L.) Merr.] production, but some areas had surprisingly low $\mathrm{K}$ values. This could result in early season plant $\mathrm{K}$ deficiencies if no-tillage practices are used (Karlen and Kovar, 2005) to reduce soil erosion. Therefore, since reduced or no-tillage practices would be beneficial to increase soil $\mathrm{C}$ levels, close monitoring of $\mathrm{K}$ levels is recommended to prevent that essential plant nutrient from limiting crop yields.

A cropping systems study in Colorado (Zobeck et al., 2008), separate from the CEAP Watershed work, was used to compare the SCI and SMAF indices for their ability to detect management differences due to tillage, cropping sequence, and $\mathrm{N}$ fertilizer rate. Both indices differentiated among the three $\mathrm{N}$ rates with the SMAF index clearly identifying the plots that received very high $\mathrm{N}$ rates from those that received none. The intermediate $\mathrm{N}$ rate, however, was not significantly different from the two extremes. In contrast, the SCI identified distinct differences among all $\mathrm{N}$ rates, but the differences were the same as those found for crop yields and residue returned to the soil. The SMAF index was more sensitive and showed more distinct differences among crop management systems. The SMAF index values were reduced as tillage intensity increased and residue cover decreased.

In a Nebraska study, the SMAF was used to develop methods for conducting soil management assessments within spatially variable fields. Apparent electrical conductivity $\left(E_{a}\right)$ was intensively sampled for an entire field near Carleton, NE to evaluate spatial variability for several soil indicators. The predominant soil series at the site is a Muir silt loam (fine-silty, mixed, superactive mesic cumulic Haplustoll). The EC a survey was conducted using a Geonics EM-38 (Geonics Limited, Mississauga, ON, Canada) mounted on a nonmetallic sled pulled behind an all terrain vehicle. ${ }^{1}$ All data was georeferenced as the survey was conducted with readings logged every $5 \mathrm{~s}$. The survey consisted of 25 transects ( $20 \mathrm{~m}$ apart) and resulted in a total of $1958 \mathrm{EC}_{\mathrm{a}}$ measurements. The survey data were processed using the ESAP software package (Lesch et al., 2000). This program uses spatial statistics to select sampling locations that reflect the observed spatial variability in $\mathrm{EC}_{\mathrm{a}}$ (Corwin and Lesch, 2003). Measured indicator data were also collected for 20 locations throughout the field. At each location a soil core was collected from the 0 - to $90-\mathrm{cm}$ depth and sectioned into 0 - to 15-, 15- to 30-, 30- to 60-, and 60to $90-\mathrm{cm}$ increments, air-dried, and sieved. Soil bulk density, $\mathrm{pH}$, electrical conductivity, organic matter content, and Bray-available $\mathrm{P}$ were determined.

The measured soil quality indicator data from the 20 points were used to calibrate the ESAP readings for those same points by calculating regression equations. Statistically

\footnotetext{
${ }_{1}^{1}$ Mention of trademark, proprietary product, or vendor is for information only and does not constitute a guarantee or warranty of the product by the USDA or imply its approval to the exclusion of other products or vendors that may also be suitable.
} 
Table 3|1. Coefficient of determination $\left(r^{2}\right)$ between Apparent Electrical Conductivity and select soil indicators for a Muir silt loam in southeastern Nebraska, USA.

$\begin{array}{lll}\text { Indicator } & r^{2} & p \text { value } \\ \text { Bulk density } & 0.47 & 0.014 \\ \text { Electrical conductivity } & 0.86 & 0.001 \\ \mathrm{pH} & 0.63 & 0.002 \\ \text { Bray phosphorus } & 0.68 & 0.001 \\ \text { Soil organic matter } & 0.87 & 0.001\end{array}$

significant relationships were determined (Table 3|1) for five of the indicators currently being used by the SMAF to index soil quality. The calibration equations were then used to estimate indicator values at the other 1938 EC $_{a}$ sample locations. The 1958 indicator values were then scored using the SMAF (Wienhold et al., 2008).

Values for $\mathrm{EC}_{\mathrm{a}}$ ranged from 12 to $62 \mathrm{dS}$ $\mathrm{m}^{-1}$ with high values observed in the northwest and southeast portions of the field and low values observed in the middle of the field. Salinity is not an issue at this site, so the variation in $\mathrm{EC}_{\mathrm{a}}$ is most likely due to variation in clay content, soil organic matter content, and depth of topsoil (Johnson et al., 2001; Grigera et al., 2006). Values for Bray available $P$ ranged from 3 to $45 \mathrm{mg}$ $\mathrm{kg}^{-1}$ with high values on both ends and low values in the middle of the field. All values were below the threshold value $(100 \mathrm{mg}$ $\mathrm{kg}^{-1}$ ) where the potential for environmental contamination is a concern and the SMAF scoring curve begins to lower the relative score (Andrews et al., 2004). Overall, this indexing approach was useful for identifying areas where additional $\mathrm{P}$ fertilizer would probably result in a positive yield response and where additional applications would not be beneficial.

These three studies and many others not reported here have demonstrated that indices can help quantify effects of agricultural management practices. Further assessments using the SMAF at field, farm, and watershed scales are needed, but preliminary results suggest this approach is appropriate and consistent with the goals stated in the publication, Soil and Water Quality: An Agenda for Agriculture (National Research Council, 1993).

\section{On-Going Improvements for Soil Quality Indexing}

The Soil and Water Conservation Society (2008) recently published results from an expert consultation that identified actions needed for more comprehensive soil assessment, management, and planning tools. That panel evaluated several soil management assessment tools, including the SMAF and the SCI. One recommendation was that the number of available scoring curves for interpreting measured soil indicators in the SMAF be increased. The original version of the SMAF (Andrews et al., 2004) had scoring curves for 10 soil attributes, but more than 60 other attributes were identified as having potential for being assessment indicators.

The approach being used to develop scoring curves for the SMAF involves a number of steps. The first is to identify a soil indicator that responds to management and affects a soil function of interest. Data sets containing indicator values and measures of soil function, preferably over a range of environmental conditions, must be identified or collected. These data sets are used to determine the shape of the curvilinear relationship between the indicator and the soil function and then to develop an algorithm describing that relationship. Abiotic factors that cause the relationship to change or the expected range to shift are identified to allow for appropriate interpretation of the indicator within its environmental context. Coefficients or logic statements modify each algorithm to mimic these environmental factors. The algorithm is then programmed into the SMAF and validated using additional data sets.

Recent efforts to develop additional scoring curves include Wienhold et al. (2009), who developed curves for a physical soil attribute (water-filled pore space), a chemical soil attribute (soil test $\mathrm{K}$ ), and a biological soil attribute ( $\beta$-glucosidase activity). Stott et al. (2010) also developed scoring curves for a suite of soil enzymes by using original data relating measured soil enzyme activity to management outcomes.

Further development of indices for soil quality assessment will be a continuous process, fostered by incremental improvements in our understanding of physical, chemical, and biological soil processes, as well as how they can be most effectively quantified. Assessing soil functions requires not 
only current soil science studies, but also information from associated disciplines such as geosciences, biology, hydrology, and engineering. Since soil quality depends on soil processes (Wagenet and Hutson, 1997), many are concerned about interpreting diverse soil functions with scores or indices based on one-time, snap-shot measurements of soil properties.

Directly quantifying capacities of soil functions and their associated processes is essential. The development of pedotransfer functions that emphasize soil processes and functions would also be useful to help calculate various soil capacities (Wösten, 1997). Applying the basic concepts and principles of soil-water-landscape dynamics being addressed by hydropedologists (Lin, 2003) will also enlighten the process-based indexing of soil quality.

Currently, the capacities for some soil functions such as soil resistance and resilience to change in function are not well understood, and it is therefore very difficult to develop reliable indices for quantifying such functions. One major difficulty with predicting each soil's resistance and resilience is that it will vary depending not only on inherent and dynamic (management induced) soil properties but also with type and intensity of soil disturbance and the specific functions of interest. In other words, one soil will have numerous resistances and resiliencies for different functions and disturbances. With a greater focus on soil quality and its relationship to environmental and ecological issues, we anticipate the soil functions influencing water quality and air quality will become components for holistic environmental quality assessments, with predictions of resistance and resilience a natural corollary of this work

\section{Future Indexing Efforts}

As indices to assess soil quality continue to evolve and improve, one of the future efforts to meet various resource management needs will be the development of soil quality information systems. An ideal soil quality information system would include a combination of soil quality databases, assessment tools, predictive models, and decision-making tools. To provide for a variety of users, this system would be expected to provide not only soil quality assessment scores and indices over time but also compile data for determining soil capacities for diverse uses and the outcomes of those uses. The system would also provide inputs for environmental modeling and/or farm bill program evaluations. This soils information system would be open, allowing the introduction of new soil ecosystem functions and soil indicators or for renewing existing algorithms when an improved understanding of soil properties and processes necessitates change. Some current soil databases will be valuable to support the development of such systems. The STATSGO and SSURGO databases provide rich soil information for inherent soil quality assessment at different scales. The Natural Resources Inventory (NRI) program of the USDA-NRCS has performed nationwide resources monitoring every 4 yr since 1984 and now monitors a subset of points annually. The NRI datasets could provide valuable spatial and temporal land use and management information for plotting soil quality trends in this country. Combining CEAP with SMAF scoring (Potter et al., 2006) could provide contextual meaning to modeling outcomes that would be a valuable predictive tool. These databases could help develop national soil quality criteria and also improve soil quality tool development and validation. In the mean time, NRI and other soil databases could facilitate development of soil quality monitoring tools as suggested by Karlen et al. (2003). New, but not well quantified soil functions, such as resistance and resilience, urban soil quality assessment, and soil quality change patterns due to global warming, could also become major components of an extensive soils information system. Further improvements could be achieved as geographic information system (GIS), remote sensing, modeling, and data mining tools are developed and customized for indexing soil quality with regard to various needs and applications.

The soil quality information system should also include "prediction and uncertainty" guidelines to help interpret the indices and soil quality assessments. This is consistent with predictions by Tugel et al. (2005), who proposed a blueprint for quantifying soil changes through soil survey and decision-making processes. They also suggested that dynamic soil properties should be integrated into future soil databases. An ideal soil quality 
information system would not only assess the current states of soil quality but also provide trends and decision-making tools. Development of a soil quality information system such as this could be a pivotal bridge between soil science research and soil management practices.

\section{Using Indices to Improve Soil Management}

How might soil indices such as those described above be used to improve soil management decisions? One of the first applications would be to enhance routine soil test information that currently focuses almost exclusively on soil chemical or fertility parameters. Applying indices that account for physical, chemical, and biological properties and processes is the focus of the Cornell Soil Health Assessment program (Gugino et al., 2007). Current efforts to develop sustainable feedstock supplies for biofuel and other bioproducts offer another immediate application for indices such as the SMAF since initial estimates of feedstock supply were based solely on retaining sufficient surface cover to protect against wind and water erosion and not to sustain soil carbon (Wilhelm et al., 2007). Another application could be to help set land rental and purchase value based not only on potential productivity but also on the current physical, chemical, and biological status of the soil resource. This is an underlying reason for development of procedures for assessing soil change within soil survey and vegetation and ecological site inventories by the NRCS (Tugel et al., 2009). The critical point associated with these and other indexing applications is that soils are living, dynamic, and everchanging bodies that are affected by our soil management decisions. Responses may be immediate, but more likely will be more insidious and hard to identify unless all aspects-physical, chemical, and biological-are monitored on a routine basis, perhaps every 3 to 5 yr. Incorporating such monitoring into long-range soil management plans will undoubtedly benefit not only the land owner and manager, but many others dependent on the ecological services that soil resources provide.

\section{Summary}

The importance and need for indices to guide improved soil management have become well established during the past three decades. As a result, efforts to develop soil quality assessment tools are underway and expected to go through continued development for several years. The soil quality assessment process is expected to be a holistic approach for examining multiple soil functions regarding productivity, environmental buffering, and ecosystem sustainability. Tools sensitive to soil biological, chemical, and physical indicators are needed to fully evaluate the impact of soil management decisions, such as when and where to harvest crop residues for biofuel feedstocks or when, where, and how to apply animal manures. The AEPAT, SCI, Cornell Soil Health Assessment, and SMAF are in various stages of development, release, refinement, or dormancy. The SCI has been incorporated into RUSLE2 software and is being used by the NRCS to assist with some program decisions. The Cornell Soil Health Assessment was successfully used on a trial basis in 2008 for several participatory research studies in New England. The SMAF has been evaluated at several scales and appears to be sensitive to various management scenarios. Scoring curves for three additional indicators (water-filled pore space, soil-test $K$, and the soil enzyme $\beta$-glucosidase were recently developed. Opportunities exist for adding many additional indices to the framework to make the tool even more robust and useful. Regardless of past perceptions of soil quality, we invite all readers to join in a concerted effort to move soil quality assessment beyond single factor analyses in a meaningful way so that soil management practices can be improved and everyone can benefit from our better understanding "The Final Frontier."

\section{References}

Anderson, M., and R. Magleby. 1997. Land and soil quality. p. 41-49. In Agricultural resources and environmental indicators. Agric. Handb. AH712. Available at http://www.ers.usda.gov/publications/arei/ah712/ AH71213a.PDF (verified 30 Aug. 2010).

Andrews, S.S., and C.R. Carroll. 2001. Designing a decision tool for sustainable agroecosystem management: Soil quality assessment of a poultry litter management case study. Ecol. Appl. 11(6):1573-1585.

Andrews, S.S., D.L. Karlen, and C.A. Cambardella. 2004. The soil management assessment framework: A quantitative evaluation using case studies. Soil Sci. Soc. Am. J. 68:1945-1962. 
Andrews, S.S., D.L. Karlen, and J.P. Mitchell. 2002a. A comparison of soil quality indexing methods for vegetable production systems in northern California. Agric. Ecosyst. Environ. 1760:1-21.

Andrews, S.S., J.P. Mitchell, R. Mancinelli, D.L. Karlen, T.K. Hartz, W.R. Horwath, G.S. Pettygrove, K.M Scow, and D.S. Munk. 2002b. On-farm assessment of soil quality in California's Central Valley. Agron. J. 94:12-23.

Baumhardt, R.L. 2003. Dust Bowl era. p. 187-191. In B.A. Stewart and T.A. Howell (ed.) Encyclopedia of water science. Marcel-Dekker, New York.

Baveye, P. 2006. A future of soil science. J. Soil Water Conserv. 61:148-151.

Borggaard, O.K. 2006. Future of soil science. p. 19-21. In A.E. Hartemink (ed.) The future of soil science. International Union of Soil Sciences (IUSS), Wageningen, The Netherlands.

Bouma, J. 2002. Land quality indicators of sustainable land management across scales. Agric. Ecosyst. Environ. 88:129-136

Bouma, J. 2004. Implementing soil quality knowledge in land-use planning. p. 283-296. In P. Schjønning et al. (ed.) Managing soil quality: Challenges in modern agriculture. CAB International, Wallingford, UK.

Bouma, J. 2005. Soil scientists in a changing world. Adv. Agron. 88:67-96.

Carter, M.R. 2002. Soil quality for sustainable land management: Organic matter and aggregation interactions that maintain soil functions. Agron. J. 94:38-47.

Commission of the European Communities. 2006. Questions and answers on the Thematic Strategy on soil protection. Available at http://europa.eu/rapid/pressReleasesAction.do?reference=MEMO/06/341\&forma $\mathrm{t}=\mathrm{HTML} \&$ aged $=0$ \&language $=\mathrm{EN} \&$ guiLanguage $=\mathrm{en}$ (verified 30 Aug. 2010)

Corwin, D.L., and S.M. Lesch. 2003. Application of soil electrical conductivity to precision agriculture: Theory, principles, and guidelines. Agron. J. 95:455-471.

Diamond, J. 2005. Collapse: How societies choose to fail or succeed. Viking Press, New York.

Doran, J.W., and T.B. Parkin. 1994. Defining and assessing soil quality. p. 3-21. In J.W. Doran, et al. (ed.) Defining soil quality for a sustainable environment. SSSA Spec. Publ. 35. SSSA and ASA, Madison, WI.

Doran, J.W., M. Sarrantonio, and M.A. Liebig. 1996. Soil health and sustainability. Adv. Agron. 56:1-55.

Grigera, M.S., R.A. Drijber, K.M. Eskridge, and B.J. Wienhold. 2006. Soil microbial biomass relationships with organic matter fractions in a Nebraska corn field mapped using apparent electrical conductivity. Soil Sci. Soc. Am. J. 70:1480-1488.

Gugino, B.K., O.J. Idowu, R.R. Schindelbeck, H.M. van Es, D.W. Wolfe, B.N. Moebius, J.E. Thies, and G.S. Abawi. 2007. Cornell Soil Health Assessment Training Manual. ed. 1.2.2. Available at http://soilhealth cals.cornell.edu (verified 30 Aug. 2010). Cornell University, Geneva, NY.

Harris, R.F., D.L. Karlen, and D.J. Mulla. 1996. A conceptual framework for assessment and management of soil quality and health. p. 61-82. In J.W. Doran and A.J. Jones (ed.) Methods for assessing soil quality. SSSA Spec. Publ. 49. SSSA, Madison, WI.

Hart, J. 2009. Ground lost and gained in 75 years of conservation at Coon Creek. p. 102A-106A. In M. Anderson-Wilk (ed.) Relationship with the land. Soil Water Conserv. Soc., Ankeny, IA.

Herrick, J.E. 2000. Soil quality: An indicator of sustainable land management. Appl. Soil Ecol. 15:75-83.

Hillel, D. 1991. Out of the Earth: Civilization and the life of the soil. Univ. of California Press, Los Angeles.

Hubbs, M.D., M.L. Norfleet, and D.T. Lightle. 2002. Interpreting the soil conditioning index. p. 192196. In E.V. Santen (ed.) Making conservation tillage conventional: Building a future on 25 years of research. Proc. 25th Annual Southern Conservation Tillage Conf. for Sustainable Agriculture. Spec. Rep. 1. Alabama Agric. Exp. Stn. and Auburn University, Auburn, AL.

Johnson, C.K., J.W. Doran, H.R. Duke, B.J. Wienhold, K.M. Eskridge, and J.F. Shanahan. 2001. Field-scale electrical conductivity mapping for delineating soil condition. Soil Sci. Soc. Am. J. 65:1829-1837.

Karlen, D.L., S.S. Andrews, and J.W. Doran. 2001. Soil quality: Current concepts and applications. Adv. Agron. 74:1-40.

Karlen, D.L., S.S. Andrews, B.J. Wienhold, and J.W. Doran. 2003. Soil quality: Humankind's foundation for survival. J. Soil Water Conserv. 58:171-179.

Karlen, D.L., E.G. Hurley, S.S. Andrews, C.A. Cambardella, D.W. Meek, M.D. Duffy, and A.P. Mallarino. 2006. Crop rotation effects on soil quality at three northern Corn/Soybean Belt locations. Agron. J. 98:484-495.

Karlen, D.L., and J.L. Kovar. 2005. Is K the Cinderella nutrient for reduced tillage systems? Fluid J. 13:8-11.

Karlen, D.L., M.D. Tomer, J. Neppel, and C.A. Cambardella. 2008. A preliminary watershed scale soil quality assessment in north central Iowa, USA. Soil Tillage Res. 99:291-299.

Karlen, D.L., N.C. Wollenhaupt, D.C. Erbach, E.C. Berry, J.B. Swan, N.S. Eash, and J.L. Jordahl. 1994a. Crop residue effects on soil quality following 10 years of no-till corn. Soil Tillage Res. 31:149-167.

Karlen, D.L., N.C. Wollenhaupt, D.C. Erbach, E.C. Berry, J.B. Swan, N.S. Eash, and J.L. Jordahl. 1994b. Longterm tillage effects on soil quality. Soil Tillage Res. 32:313-327.

Krupenikov, I.A. 1981. History of soil science. Nauka Publishers, Moscow, Russia.

Lal, R. 1999. Soil quality and food security: The global perspective. p. 3-16. In R. Lal (ed.) Soil quality and soil erosion. Soil Water Conserv. Soc., Inc., Ankeny, Iowa.

Lal, R. 2007. Soil science and the carbon civilization. Soil Sci. Soc. Am. J. 71:1425-1437.

Larson, W.E., and F.J. Pierce. 1991. Conservation and enhancement of soil quality. p. 175-203. In J. Dumanski et al. (ed.) Evaluation for sustainable land management in the developing world. Vol. 2. Technical papers. Proc. Int. Workshop, Chiang Rai, Thailand. 15-21 Sept. 1991. Int. Board for Soil Res. and Management, Bangkok, Thailand.

Laws, W.D. 1961. Farming systems for soil improvement in the Blacklands. Texas Research Foundation Bull. 10 Texas A\&M University, College Stn., TX.

Lesch, S.M., J.D. Rhodes, and D.L. Corwin. 2000. The ESAP-95 version 2.01R user manual and tutorial guide. Research Rep. 146. USDA-ARS, George E. Brown, Jr., Salinity Laboratory, Riverside, CA.

Letey, J., R.E. Sojka, D.R. Upchurch, D.K. Cassel, K.R. Olson, W.A. Payne, S.E. Peterie, G.H. Price, R.J. Reginato, H.D. Scott, P.J. Smethurst, and G.B. Triplett. 2003. Deficiencies in the soil quality concept and its application. J. Soil Water Conserv. 58:180-187.

Liebig, M.A., J.W. Doran, and J.C. Gardner. 1996. Evaluation of a field test kit for measuring selected soil quality indicators. Agron. J. 88:683-686.

Liebig, M.A., M.E. Miller, G.E. Varvel, J.W. Doran, and J.D. Hanson. 2004. AEPAT: A computer program to assess agronomic and environmental performance of management practices in long-term agroecosystem experiments. Agron. J. 96:109-115.

Lin, H.S. 2003. Hydropedology: Bridging disciplines, scales, and data. Vadose Zone J. 5:317-340.

Lowdermilk, W.C. 1953. Conquest of the land through seven thousand years. Agric. Bull. 99. U.S. Gov. Print. Office, Washington, DC.

Mallarino, A.P., D.J. Wittry, and P.A. Barbagelata. 2002. Iowa soil-test field calibration research update: 
Potassium and the Mehlich-3 ICP phosphorus test. ISU Dep. of Agronomy. Available at http://www.agronext. iastate.edu/soilfertility/ (verified 30 Aug. 2010).

McNeill, J.R., and V. Winiwater. 2004. Breaking the sod: Humankind, history, and soil. Science 304:1627-1629.

National Research Council. 1993. Soil and water quality: An agenda for agriculture. National Academy Press, Washington, DC.

Patzel, N., H. Sticher, and D.L. Karlen. 2000. Soil fertility-Phenomenon and concept. J. Plant Nutr. Soil Sci. 163:129-142.

Potter, S.R., S.S. Andrews, J.D. Atwood, R.L. Kellogg, J. Lemunyon, M.L. Norfleet, and D. Oman. 2006. Model simulation of soil loss, nutrient loss, and change in soil organic carbon associated with crop production. USDA-NRCS Conservation Effects Assessment Report. June 2006. Available at http://www.nrcs.usda. gov/technical/nri/ceap/croplandreport/ (verified 30 Aug. 2010).

Romig, D.E., M.J. Garlynd, and R.F. Harris. 1996. Farmerbased assessment of soil quality: A soil health scorecard. p. 39-60. In J.W. Doran and A.J. Jones (ed.) Methods for assessing soil quality. SSSA Spec. Publ. 49. SSSA, Madison, WI.

Sarrantonio, M., J.W. Doran, M.A. Liebig, and J.J. Halvorson. 1996. On-farm assessment of soil quality and health. p. 83-105. In J.W. Doran and A.J. Jones (ed.) Methods for assessing soil quality. SSSA Spec. Publ. 49. SSSA, Madison, WI.

Schumacher, J.A., T.C. Kaspar, J.C. Ritchie, T.E. Schumacher, D.L. Karlen, E.R. Venteris, G.M. McCarty, T.S. Colvin, D.B. Jaynes, M.J. Lindstrom, and T.E. Fenton. 2005. Identifying spatial patterns of erosion for use in precision conservation. Soil Tillage Res. 60:355-362.

Seybold, C.A., M.J. Mausbach, D.L. Karlen, and H.H. Rogers. 1998. Quantification of soil quality. p. 387-404. In R. Lal et al. (ed.) Soil processes and the carbon cycle. CRC Press, Boca Raton, FL.

Shepherd, T.G. 2000. Visual soil assessment. Vol. 1. Field guide for cropping and pastoral grazing on flat to rolling country. horizons.mw \& Landcare Research, Palmerston North, New Zealand.

Shepherd, T.G., C.W. Ross, L.R. Basher, and S. Saggar. 2000. Visual soil assessment. Vol. 2. Soil management guidelines for cropping and pastoral grazing on flat to rolling country. horizons.mw \& Landcare Research. Palmerston North, New Zealand.

Soil and Water Conservation Society. 2008. BEYOND T: Informing sustainable soil management. Available at http://www.swcs.org/en/publications/beyond_t/ (verified 30 Aug. 2010). Soil Water Conserv. Soc., Ankeny, IA

Sojka, R.E., and D.R. Upchurch. 1999. Reservations regarding the soil quality concept. Soil Sci. Soc. Am J. 63:1039-1054.

Sojka, R.E., D.R. Upchurch, and N.E. Borlaug. 2003. Quality soil management or soil quality management: Performance versus semantics. Adv. Agron. 79: 1-68.

Sparling, G.P., and L.A. Schipper. 2002. Soil quality at a national scale in New Zealand. J. Environ. Qual. 31:1848-1857.

Sparling, G.P., L.A. Schipper, W. Bettjeman, and R. Hill. 2004. Soil quality monitoring in New Zealand: Practical lessens from a 6-year trial. Agric. Ecosyst. Environ. 104:523-534

Stott, D.E., S.S. Andrews, M.A. Liebig, B.J. Wienhold, and D.L. Karlen. 2010. Evaluation of $\beta$-glucosidase activity as a soil quality indicator. Soil Sci. Soc. Am. J. 74:107-119.
Sugden, A., R. Stone, and C. Ash. 2004. Ecology in the underworld. Science 304:1613.

Tugel, A.J., J.E. Herrick, J.R. Brown, M.J. Mausbach, W. Puckett, and K. Hipple. 2005. Soil change, soil survey, and natural resources decision making: A blueprint for action. Soil Sci. Soc. Am. J. 69:738-747.

Tugel, A.J., S.A. Wills, and J.E. Herrick. 2009. Soil change guide: Procedures for soil survey and resource inventory. Version 1.1. USDA-NRCS, National Soil Survey Center, Lincoln, NE.

USDA. 1934. Yearbook of agriculture. USDA, Washington, DC.

USDA-NRCS. 1999. Soil quality test kit guide. Available at http://soils.usda.gov/sqi/assessment/files/test_kit complete.pdf (verified 30 Aug. 2010).

USDA-NRCS. 2003. Interpreting the soil conditioning index: A tool for measuring soil organic matter trends. Available at http://soils.usda.gov/SQI/management/ files/sq_atn_16.pdf (verified 30 Aug. 2010).

USDA-NRCS. 2006. Productive lands \& healthy environment: Natural Resources Conservation Service Strategic Plan 2005-2010. USDA-NRCS, Washington, DC.

Wagenet, R.J., and J.L. Hutson. 1997. Soil quality and its dependence on dynamic physical processes. J. Environ. Qual. 26:41-48.

Warkentin, B.P., and H.F. Fletcher. 1977. Soil quality for intensive agriculture. p. 594-598. Proceedings of the International Seminar on Soil Environment and Fertility Management in Intensive Agriculture. Society of Science of Soil and Manure, National Institute of Agricultural Science, Tokyo.

Whitney, M. 1909. Soils of the United States: Based upon the work of the Bureau of Soils to January 1, 1908 . Bureau of Soils Bull. 55. USDA, Gov. Print. Office, Washington, DC.

Wienhold, B.J., S.S. Andrews, H. Kuykendall, and D.L. Karlen. 2008. Recent advances in soil quality assessment in the United States. J. Indian Soc. Soil Sci. 56:237-246.

Wienhold, B.J., D.L. Karlen, S.S. Andrews, and D.E. Stott. 2009. Protocol for Indicator Scoring in the Soil Management Assessment Framework (SMAF). Renewable Agric. Food Sys. 24(4):260-266.

Wienhold, B.J., J.L. Pikul, Jr., M.A. Liebig, M.M. Mikha, G.E. Varvel, J.W. Doran, and S.S. Andrews. 2006 Cropping system effects on soil quality in the Great Plains: Synthesis from a regional project. Renew. Agric. Food Sys. 21:49-59.

Wilhelm, W.W., J.M.-F. Johnson, D.L. Karlen, and D.T Lightle. 2007. Corn stover to sustain soil organic carbon further constrains biomass supply. Agron. J. 99:1665-1667.

Wösten, J.H.M. 1997. Pedotransfer functions to evaluate soil quality. p. 221-245. In E.G. Gregorich and M.R Carter (ed.) Soil quality for crop production and ecosystem health. Developments in Soil Science. Elsevier, Amsterdam, The Netherlands.

Yaalon, H.D. 1997. Introducing soils as an object of study. p. 1-67. In D.H. Yaalon and S. Berkowicz (ed.) History of soil science. Verlag GMBH, Reiskerchen, Germany.

Zobeck, T.M., J. Crownover, M. Dollar, R.S. Van Pelt, V. Acosta-Martinez, K.F. Bronson, and D. R. Upchurch. 2007. Investigation of soil conditioning index values for southern High Plains agroecosystems. J. Soil Water Conserv. 62:433-442.

Zobeck, T.M., A.D. Halvorson, B.J. Wienhold, V. AcostaMartinez, and D.L. Karlen. 2008. Comparison of two soil quality indexes to evaluate cropping systems in northern Colorado. J. Soil Water Conserv. 63:329-338. 